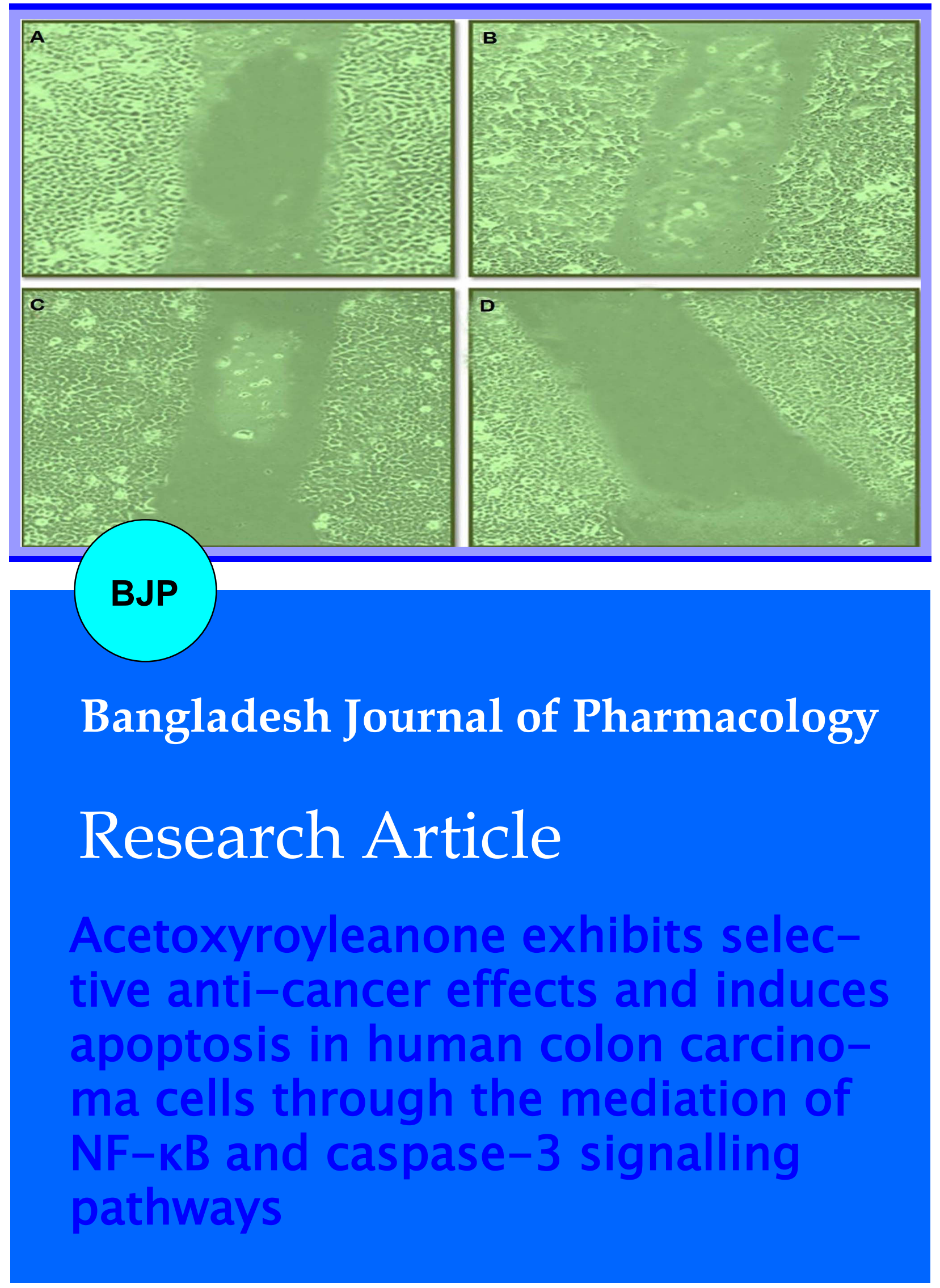


Abstracted/indexed in Academic Search Complete, Asia Journals Online, Bangladesh Journals Online, Biological Abstracts, BIOSIS Previews, CAB Abstracts, Current Abstracts, Directory of Open Access Journals, EMBASE/Excerpta Medica, Google Scholar, HINARI (WHO), International Pharmaceutical Abstracts, Open J-gate, Science Citation Index Expanded, SCOPUS and Social Sciences Citation Index;

ISSN: $1991-0088$

\title{
Acetoxyroyleanone exhibits selective anti-cancer effects and induces apoptosis in human colon carcinoma cells through the mediation of NF-KB and caspase-3 signalling pathways
}

\author{
Xiao-Jun Zhong', Hui Jia², Ji-Long Huㅜ, Fei Le4 and Xiao-Ming Zhong5 \\ ${ }^{1}$ Department of Oncology, The First Affiliated Hospital of Nanchang University, Nanchang 330 006, Jiangxi \\ Province, China; ${ }^{2}$ Departments of Internal Medicine-Oncology, Shandong Cancer Hospital and Institute, Jinan \\ 250 117, Shandong Province, China; ${ }^{3}$ Department of Tumor Abdominal Surgery, Jiangxi Tumor Hospital, \\ Nanchang 330 029, Jiangxi Province, China: ${ }^{4}$ Department of Head and Neck Surgery, Jiangxi Province Tumor \\ Hospital, Nanchang 330 029, Jiangxi Province, China; ${ }^{5}$ Department of Tumor Radiotherapy and Chemotherapy, \\ Jiangxi Tumor Hospital, Nanchang 330 029, Jiangxi Province, China.
}

\begin{tabular}{|c|c|}
\hline \multicolumn{2}{|l|}{ Article Info } \\
\hline Received: & 27 July 2015 \\
\hline Accepted: & 26 August 2015 \\
\hline Available Online: & 1 January 2016 \\
\hline \multicolumn{2}{|c|}{ DOI: 10.3329/bjp.v11i1.24339 } \\
\hline \multicolumn{2}{|c|}{$\begin{array}{l}\text { Cite this article: } \\
\text { Zhong XJ, Jia H, Hu JL, Le F, Zhong } \\
\text { XM. Acetoxyroyleanone exhibits se- } \\
\text { lective anti-cancer effects and induces } \\
\text { apoptosis in human colon carcinoma } \\
\text { cells through the mediation of NF-kB } \\
\text { and caspase-3 signalling pathways. } \\
\text { Bangladesh J Pharmacol. 2016; 11: } 141 \\
-47 \text {. }\end{array}$} \\
\hline
\end{tabular}

\section{Abstract}

The objective of the current study was to evaluate the antiproliferative and apoptotic activities of acetoxyroyleanone against various cancer cells along with studying its effect on chromatin condensation, NF-kB and caspase-3 expressions and cell migration. 3-(4,5-dimethylthiazol-2-yl)-2,5-diphenyl tetrazolium bromide assay was used to evaluate cell viability while as fluorescence microscopy revealed the effects of acetoxyroyleanone on cellular morphology of Colo-205 cells. Western blotting revealed effects on NF-kB and caspase- 3 expressions. The results revealed that acetoxyroyleanone induced potent and dose-dependent antiproliferative effects against a range of cancer cell lines with Colo-205 being the most susceptible cell line. However, it required six to eight times higher concentration of acetoxyroyleanone to induce $50 \%$ cell death in normal epithelial (fR-2) cell line. Further, following acetoxyroyleanone treatment to Colo-205, it was observed that acetoxyroyleanone induced substantial down-regulation of $\mathrm{NF}-\mathrm{kB}$ and up-regulation of caspase-3 expressions. In addition, acetoxyroyleanone impairs cell migration, chromatin condensation, cell shrinkage and membrane blebbing.

\section{Introduction}

Colorectal carcinoma is a cancer from uncontrolled cell growth in the colon or rectum or in the appendix. The number of colorectal carcinoma cases increased to 1.3 million with more than 7 lakh deaths globally as per latest global cancer statistics (Jemal et al., 2011). Factors like cell proliferation, cancer cell migration, angiogenesis and inflammation play key roles in colorectal carcinoma (Rupnarain et al., 2004; Kinzler and Vogelstein, 1996; Rodrigues et al., 1990). Conventional chemotherapy involving 5-fluorouracil, leucovorin, capecitabine and irinotecan regimens for the treatment of colorectal cancer have inadequate efficacy and are accompanied with significant severe adverse effects.

Acetoxyroyleanone is an abietane diterpenic natural product usually isolated from various plant species particularly from Salvia species such as Salvia nemorosa and S. martiusii (da Araújo et al., 2006; Vlasova et al., 1969). Acetoxyroyleanone contains a quinone moiety as its key structural feature. It has been reported that abietane diterpenes are often reported to exhibit cytotoxic effects on cancer cell lines. It was reported that the cytotoxic activity of acetoxyroyleanone was related to the inhibition of DNA synthesis and induction of apop- 
tosis (da Araújo et al., 2006). Acetoxyroyleanone has also been reported to induce cytotoxic effects in pancreatic cancer cell line (Fronza et al., 2012). Despite this, till now, very little information exists in the literature regarding the cytotoxic molecular mechanism of action of acetoxyroyleanone.

In the present study, the molecular mechanism of action of acetoxyroyleanone is reported by studying its effects on apoptosis induction, NF-kB and caspase-3 signalling pathways.

\section{Materials and Methods}

\section{Chemicals and source of antibodies and kits}

Growth medium (MEM/RPMI), fetal calf serum, trypsin, penicillin, streptomycin, dimethyl sulfoxide, RNase, proteinase K, RIPA Buffer, bisacrylamide, SDS, ([3-(4, 5dimethylthiazol-2-yl)-2,5-diphenyl tetrazolium bromide]) dye, acrylamide, ammonium persulfate, 2-mercaptoethanol, and Tris-base were obtained from Hangzhou Sijiqing Biological Products Co. Ltd, China. Chemiluminescent Western blotting kit (Millipore), Quanti Pro BCA assay kit, 96 and 6 well plate (Iwaki), triton X (Hi-Media), Tris-EDTA (Hi-Media), acetic acid (Rankem), ELISA plate reader (Bio-Rad). NFkB (p65), caspase-3 antibodies were purchased from Millipore Pvt. Ltd. Acetoxyroyleanone was purchased from Sigma Chemical Company (USA), and $100 \mathrm{mg} / \mathrm{mL}$ solution dissolved in dimethyl sulfoxide was stored at $-20^{\circ} \mathrm{C}$ prior to use.

\section{Cell lines, growth medium and treatment conditions}

Human cancer cell lines; prostate (PC-3), leukemia (THP-1), colon (Colo-205, Caco-2), breast (T47D,MCF7), pancreatic (MiaPaca-2) and normal epithelial (fR-2) were procured from Shanghai Institute of Cell Resource Center of Life Science (China). Cells were grown in Minimum Essential Medium and Roswell Park Memorial Institute medium supplemented with $10 \%$ fetal calf serum and $1 \%$ penicillin. Penicillin was dissolved in phosphate buffered saline and sterilized by filtering through $0.2 \mu \mathrm{m}$ filter in laminar air flow hood. Cells were cultured in $\mathrm{CO}_{2}$ incubator (New Brunswick, Galaxy 170R, eppendroff) with an internal atmosphere of $95 \%$ air and $5 \% \mathrm{CO}_{2}$ gas and the cell lines were maintained at $37^{\circ} \mathrm{C}$. The media was stored at low temperature $\left(2-8^{\circ} \mathrm{C}\right)$ and the medium for cryopreservation contained $20 \%$ fetal calf serum and $10 \%$ dimethyl sulfoxide in the growth medium.

\section{MTT assay for cell viability evaluation}

Cell viability was measured using [3-(4, 5-dimethylthiazol-2-yl)-2, 5-diphenyl tetrazolium bromide] (MTT) assay. Different cell lines were seeded in $200 \mu \mathrm{L}$ of Roswell Park Memorial Institute medium-1640 medium into 96-well plates, and cultured overnight. Then the medium was replaced with fresh RPMI-1640 or the same media containing different concentrations of acetoxyroyleanone. After a further incubation for 24 hours, $30 \mu \mathrm{L}$ of MTT ( $2 \mathrm{mg} / \mathrm{mL}$ ) was added to each well followed by 3 hours incubation. The medium was discarded and $170 \mu \mathrm{L}$ of dimethyl sulfoxide was added to each well, and incubated for $30 \mathrm{~min}$. The $\mathrm{OD}_{490} \mathrm{~nm}$ was measured. The cell viability index was calculated according to the formula:

(Experimental OD value/control OD value) $\times 100 \%$

Cytotoxicity was expressed as the concentration of acetoxyroyleanone inhibiting cell growth by $50 \%$ ( $\mathrm{IC}_{50}$ value).

\section{Preparation of whole cell lysates and Western blot analysis}

Colo-205 ( 1 x $10^{5}$ cells $/ \mathrm{mL} /$ well $)$ cells were treated with acetoxyroyleanone at $0,5,10,20$ and $30 \mu \mathrm{M}$ were suspended in cold RIPA buffer $(150 \mathrm{mM} \mathrm{NaCl}, 1.0 \%$ IGEPAL CA-630, 0.5\% sodium deoxycholate, 0.1\%SDS, $50 \mathrm{mM}$ Tris, $\mathrm{PH} 8.0$ ) for $30 \mathrm{~min}$ on ice. The lysates were vortexed and centrifuged at $12,000 \mathrm{xg}$ for $10 \mathrm{~min}$. Supernatant thus obtained was whole cell lysate and was stored at $-20^{\circ} \mathrm{C}$ for further use. Protein content was measured using bovine serum albumin as standard. 1 $\mathrm{mg} / \mathrm{mL}$ protein standard was taken and samples with unknown concentrations were plotted in a linear range of 0.5 to $30 \mu \mathrm{g} / \mathrm{mL}$ of the protein concentration and absorbance measured at $562 \mathrm{~nm}$. The above protein lysates were subjected to discontinuous SDS-PAGE at $100 \mathrm{~V}$ and electro transferred topolyvinylidene difluoride membrane (Millipore) for 2.5 hours at $120 \mathrm{~V}$ at $4^{\circ} \mathrm{C}$. The membrane was blocked with $2 \%$ skimmed milk in phosphate buffered serum for 1 hour. After blocking, the membrane was probed with specific primary antibody for overnight at $4^{\circ} \mathrm{C}$ followed by 2 times washing with tris-buffered saline for $5 \mathrm{~min}$ each. A dilution of secondary antibody (mouse and rabbit) conjugate was added for 1 hour of incubation and signals were detected using Millipore chemiluminescent Western blotting kit and analyzed using X-ray film.

\section{Cell migration assay}

Cell monolayer (90\% confluent) was allowed to become quiescent in medium with $0.1 \%$ dialyzed fetal bovine serum for 24 hours. Then cells were scraped to make a straight line wound and treated with acetoxyroyleanone for 48 hours. Photographs were taken at 48 hours and lengths of the wound were determined by Image J (version 1.46) software.

\section{Statistical evaluation}

The results of three independent experiments were expressed as the mean \pm SD. Statistical evaluation was performed using an un-paired t-test. 
Table I

$\mathrm{IC}_{50}$ value of acetoxyroyleanone against different cancer cell lines including normal epithelial cell line

\begin{tabular}{|llcc|}
\hline Tissue & Cell Line & $\begin{array}{c}\mathrm{IC}_{50}(\mu \mathrm{M}) \\
\text { (Acetoxyroyleanone) }\end{array}$ & $\begin{array}{c}\mathrm{IC} 50(\mathrm{nM}) \\
(\mathrm{BEZ}-235)\end{array}$ \\
\hline Leukemia & THP-1 & 27 & - \\
Prostate & PC-3 & $>50$ & 10 \\
Breast & T47D & 24 & - \\
Breast & MCF-7 & 28 & 10 \\
Pancreas & MiaPaCa-2 & 25 & 10 \\
Colon & Colo-205 & 12 & - \\
Colon & Caco-2 & $>50$ & - \\
Normal & fR-2 & $>50$ & \\
\hline
\end{tabular}

\section{Results}

In vitro cytotoxic effect of acetoxyroyleanone against different human cancer cell lines

In this study, in vitro inhibitory effect of acetoxyroyleanone was evaluated using the MTT viability assay against a range of cancer cell lines and $\mathrm{IC}_{50}$ after 48 hours was calculated. Initially, acetoxyroyleanone was screened (Table I) against leukemia (THP-1), prostate (PC-3), breast (MCF-7,T47D), pancreas (MiaPaca-2), colon (COLO-205, Caco-2) cancer cell lines including normal epithelial cell (fR-2) at indicated concentration $(5,10,20,30$ and $50 \mu \mathrm{M})$ for 48 hours. Acetoxyroyleanone (Figure1) shows concentration-dependent inhibitory effect on cell proliferation against THP-1, T47D, MiaPaca2 MCF-7 and Colo-205 cancer cell lines and most potent inhibition against Colo-205. The cell viability assay revealed that in Colo-205, acetoxyroyleanone $(5-50 \mu \mathrm{M})$ increased growth inhibition of 96,82 and $79 \%$ at a concentration of 50 , 30 and $20 \mu \mathrm{M}$ (Figure 2), with the calculated $\mathrm{IC}_{50}$ value of 12 $\mu \mathrm{M}$ and $10 \mathrm{nM}$ for BEZ-235 which were used as positive control (Table I). However, it required six to eight times higher concentration of acetoxyroyleanone to induce $50 \%$ cell death in normal epithelial (fR-2) cell line. Interestingly, these results also depicted that acetoxyroyleanone showed more efficiency against Colo-205 as revealed by their relative $\mathrm{IC}_{50}$ values.

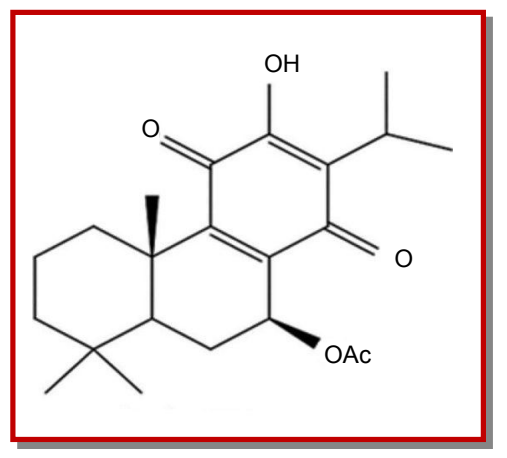

Figure 1: Chemical structure of acetoxyroyleanone
Effect of acetoxyroyleanone treatment on NF- $\kappa B$ and caspase-3 expression in Colo-205 cell line

In next experiment, the effect of acetoxyroyleanone on NF-kB and caspase-3 protein expression levels by Western blotting was observed. Following acetoxyroyleanone $(10$ and $30 \mu \mathrm{M})$ treatment for 48 hours, Western blot analysis revealed that acetoxyroyleanone decreased expression level of NF-kB (p65) and increased caspase-3 expression level (Figure 3). However, significant effect on both proteins was observed at 30 $\mu \mathrm{M}$ acetoxyroyleanone concentration as compared to untreated and BEZ-235 (10 nM) (positive control) (Figure 4), suggesting NF-kB down-regulation and caspase-3 up-regulation by acetoxyroyleanone.

\section{Treatment of acetoxyroyleanone inhibits cell migration of Colo-205 cell monolayers}

Wound closure experiments were performed to establish the inhibitory effect of acetoxyroyleanone in Colo205 cell migration. As shown in Figure 5, the wound got almost healed in untreated and slightly so at the lower concentrations $(10 \mu \mathrm{M})$ of acetoxyroyleanone. However, at higher concentration $(30 \mu \mathrm{M})$ invasiveness of Colo205 cells showed potent cell migration inhibition. Acetoxyroyleanone treatment results in significant inhibition of Colo-205 cells invasion at a concentration of $30 \mu \mathrm{M}$ compared to negative control $(0 \mu \mathrm{M})$ and positive control (BEZ-235, $10 \mathrm{nM}$ ) (Figure 6).

\section{Discussion}

In the present study, an interesting correlation was discovered for the first time between various regulatory and phenotypic events of acetoxyroyleanone with apoptosis. First, the growth inhibitory and cytotoxicity effect of acetoxyroyleanone against a panel of human cancer cell lines which include leukemia (THP-1), prostate (PC-3), breast (MCF-7, T47D), pancreas (MIAPaca2), colon (Colo-205, Caco-2) including normal 


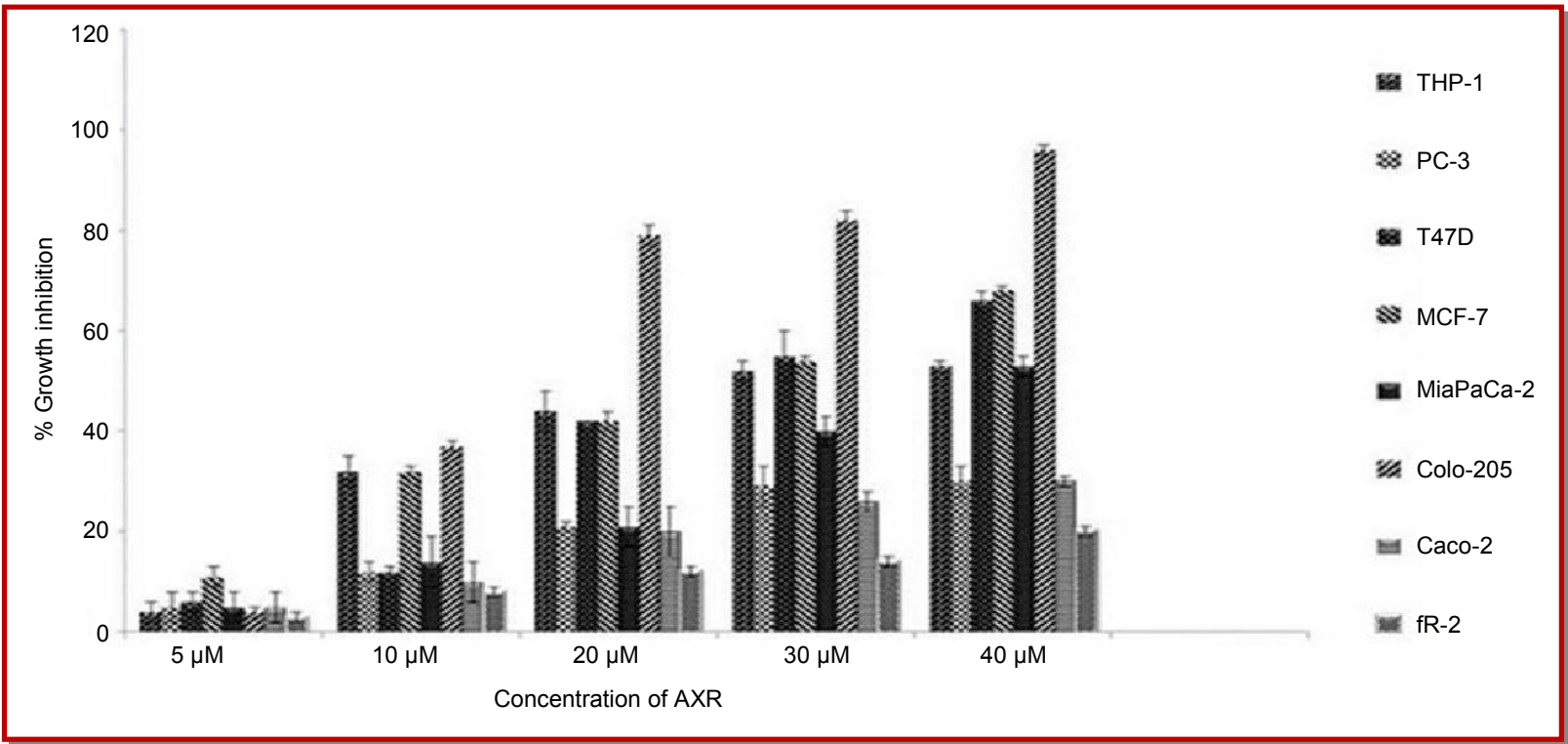

Figure 2: Growth inhibitory effect of acetoxyroyleanone against panel of cancer cell lines including normal epithelial cell line. Cells grown in 96 well plate was treated with different concentration of acetoxyroyleanone $(5,10,20,30$ and $50 \mu \mathrm{M})$. Data represent mean $\pm \mathrm{SD}(\mathrm{n}=3)$ of three repeats

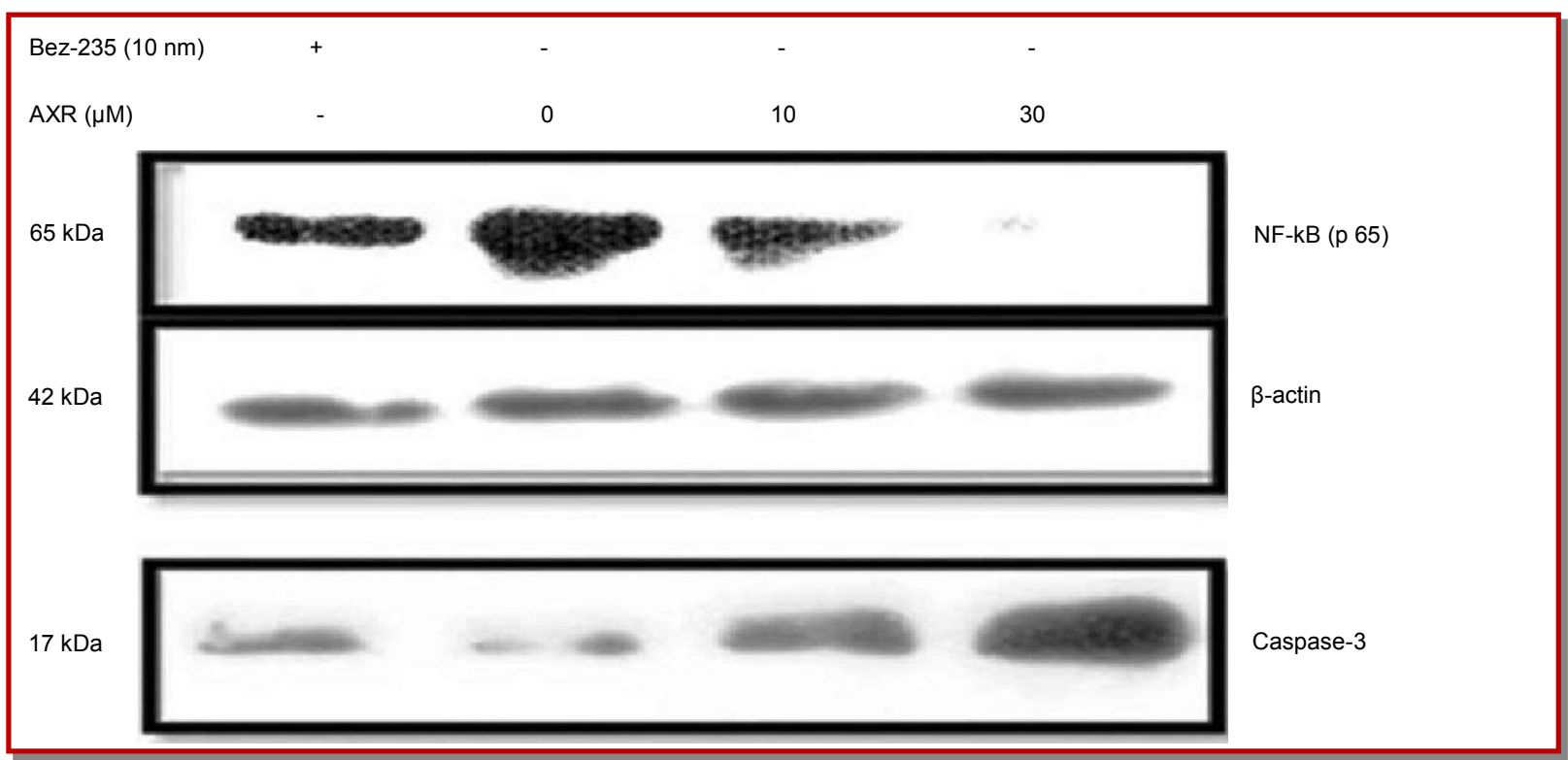

Figure 3: Western blot analysis reveals decrease in NF-kB (p65) and increase in caspase-3 expression at 10 and $30 \mu \mathrm{M}$ of acetoxyroyleanone for 48 hours incubation

epithelial cell (fR-2) was evaluated. Particularly, it was found that acetoxyroyleanone inhibits cell growth and more significantly showed concentration-dependent inhibition against a panel of cancer cell lines tested. Interestingly, maximum and potent growth inhibition following acetoxyroyleanone were observed at 50, 30 and $20 \mu \mathrm{M}$ in human colon cancer cell line i.e. Colo-205. Keeping this in view, the $\mathrm{IC}_{50}$ value of acetoxyroyleanone against all shown human cancer cell lines by cell viability assay was evaluated. The calculated $\mathrm{IC}_{50}$ values of acetoxyroyleanone were of the order of $27,24,28,25$ and $12 \mu \mathrm{M}$ for 48 hours incubation in the case of THP-1,
MCF-7, T47D, MiaPaca-2 and Colo-205 respectively. While as no significant cytotoxic effects were found in the normal epithelial cell line (fR-2). Overall, these results depicted that acetoxyroyleanone showed significant effect against Colo-205 colon cancer cell proliferation as reflected by relative $\mathrm{IC}_{50}$ value.

Since the NF-kB pathway is important for cell survival, proliferation, cell cycle progression and migration. Activation of NF-kB pathway affects regulation of proliferative, anti-apoptotic, pro-apoptotic and cell cycle regulatory molecules and therefore results in cell prolifera- 


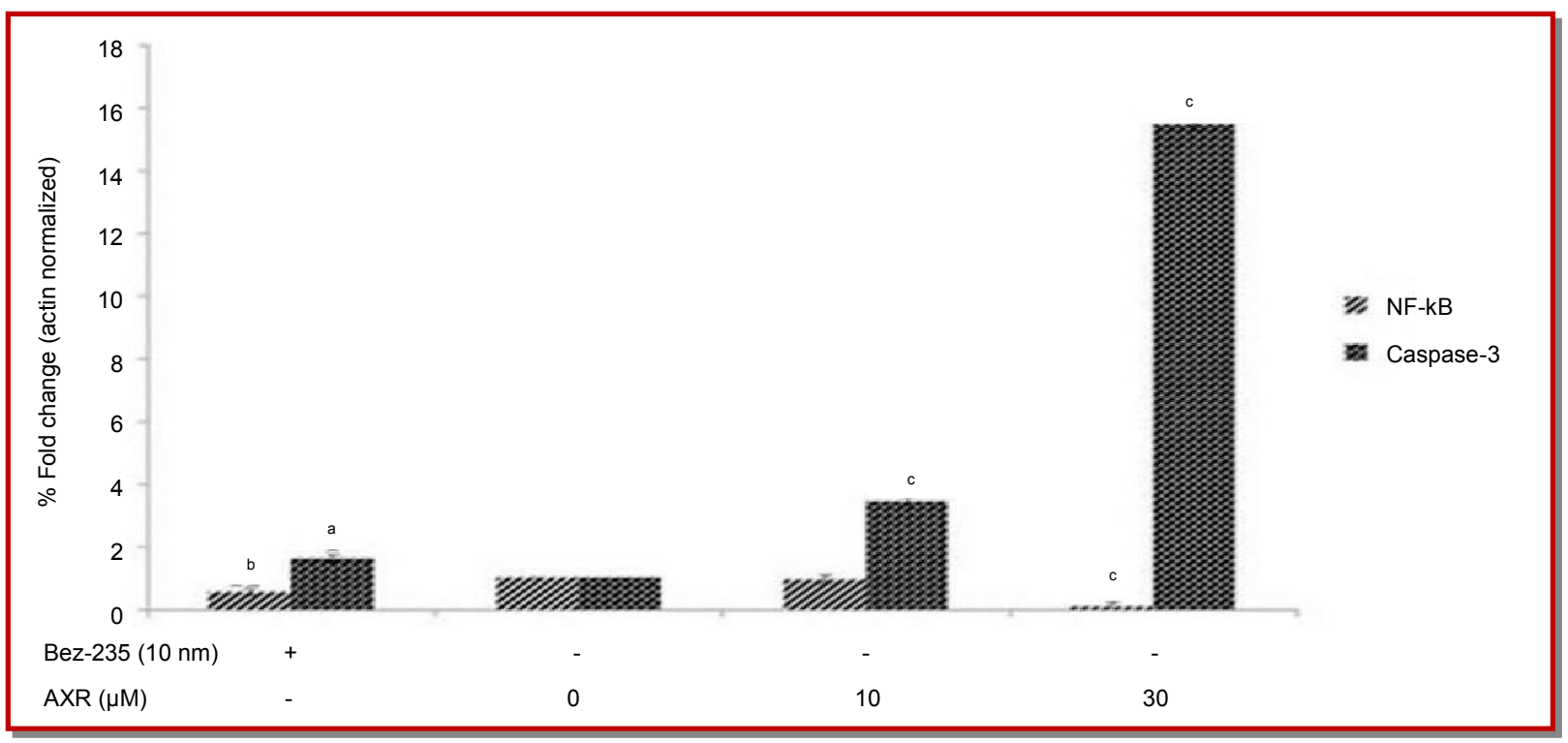

Figure 4: Acetoxyroyleanone treatment led significant decrease in NF- $\mathrm{KB}$ (p65) and increase in caspase-3 expression at $30 \mu \mathrm{M}$ with respect to untreated and BEZ-235 (10 nm); ${ }^{2} p \leq 0.05 ;{ }^{b} p \leq 0.01 ;{ }^{c} p \leq 0.001$

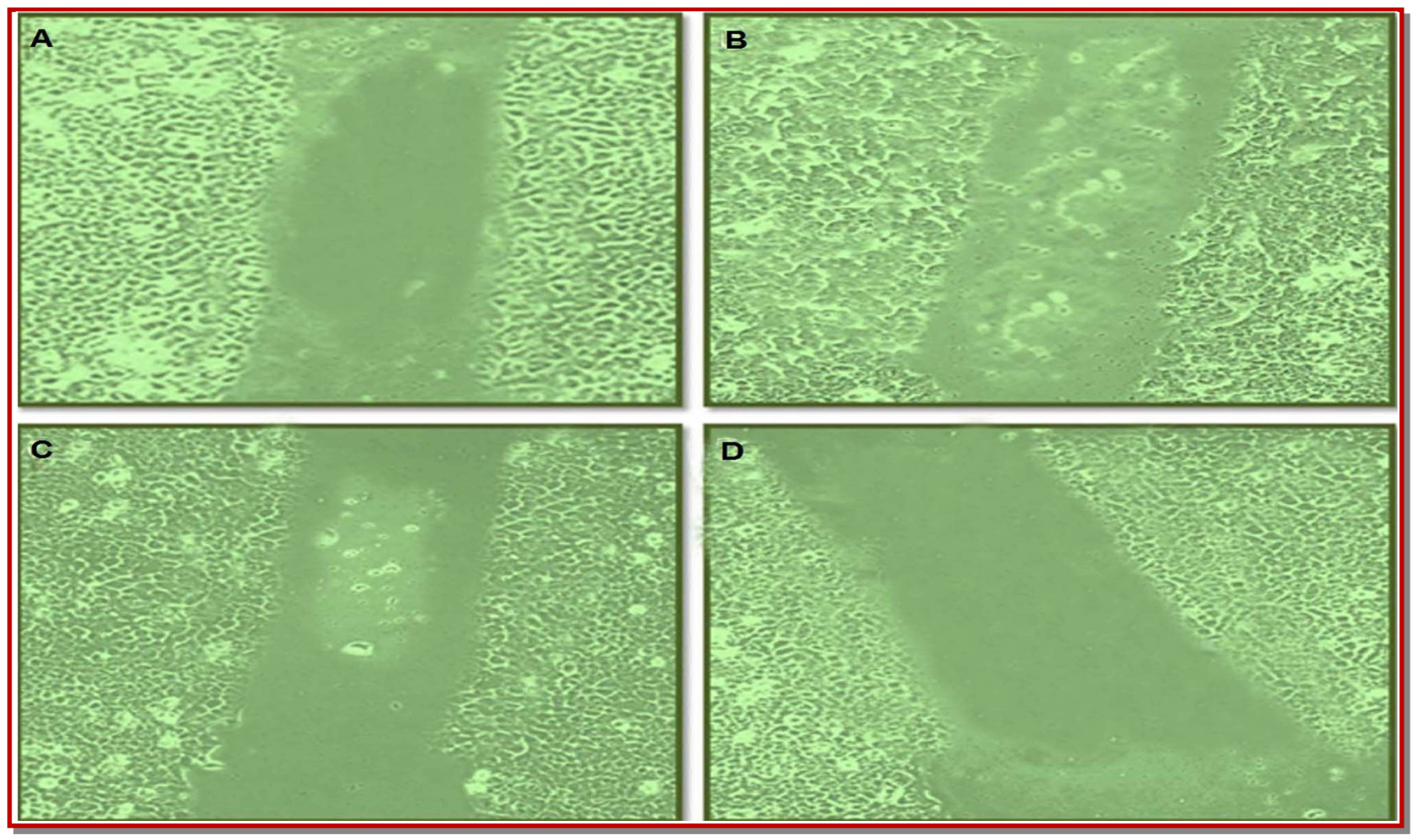

Figure 5: Effect of acetoxyroyleanone on cell migration of Colo-205 monolayers. Cells were exposed to different concentrations of acetoxyroyleanone $(10$ and $30 \mu \mathrm{M})$ for 48 hours compared to untreated. A, represents BEZ-235 treatment which was used as positive control, B, C and D represent 0,10 and $30 \mu \mathrm{M}$ concentration of acetoxyroyleanone

tion, progression and migration of numerous cancers (Bhart et al., 2003; Garg and Aggarwal, 2002). Notably, $\mathrm{NF}-\mathrm{kB}$ promotes cell survival via the induction of proteins that inhibit components of the apoptotic machinery in normal and cancerous cells (Shen and Tergaonkar, 2009). To evaluate the mechanism by which the effect of the acetoxyroyleanone occurred, further experiments of the effect of acetoxyroyleanone on NF-kB protein expression was determined. The most abundant form of NF- $\mathrm{kB}$ consists of a p50 subunit and a p65 subunit. In its inactive form, NF-kB is located in the cytoplasm, however, upon activation by various stimuli, it translocates to the nucleus, where it may activate genes leading to cell survival or proliferation 


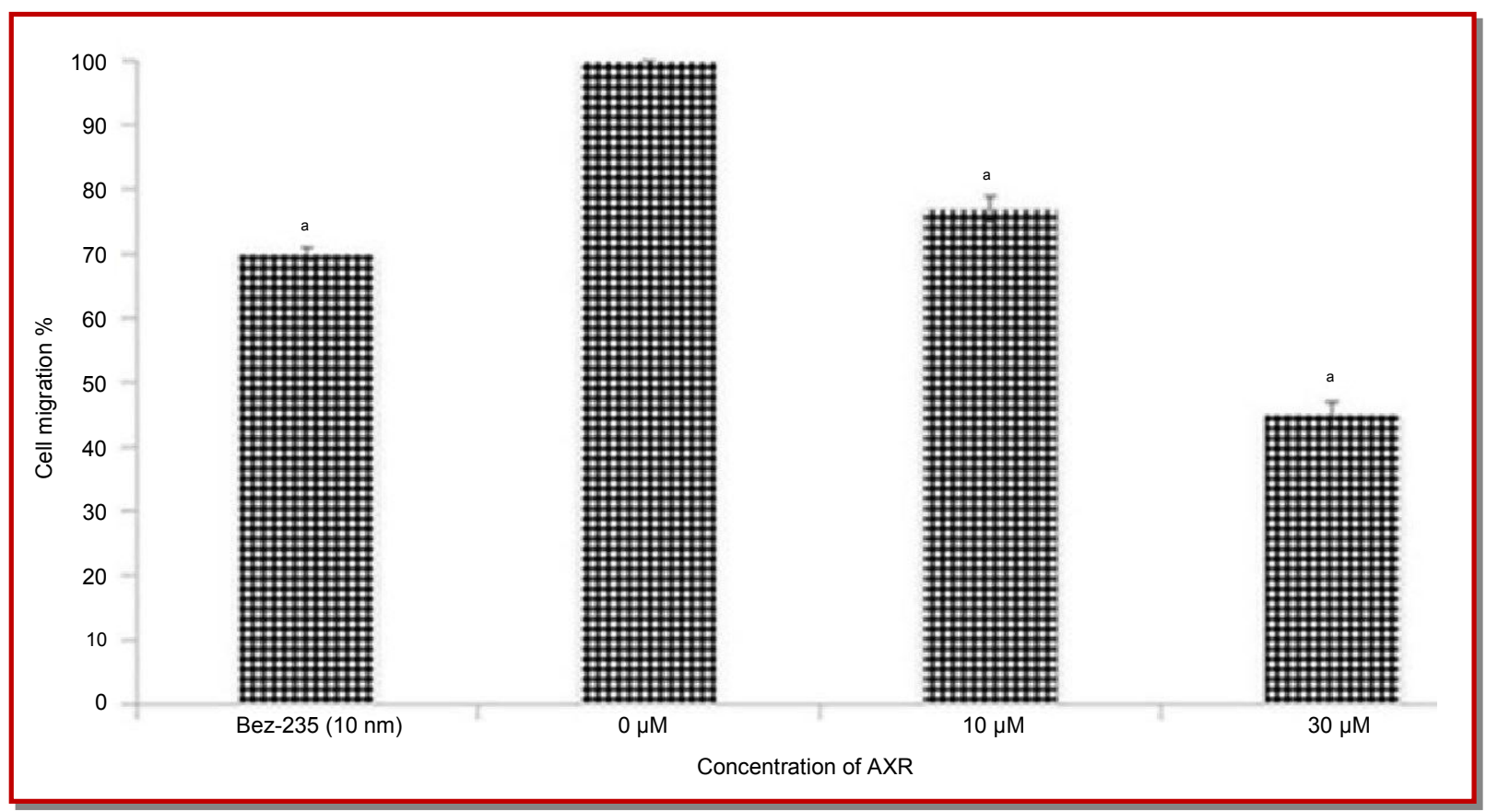

Figure 6: Significant decrease in cell migration at $30 \mu \mathrm{M}$ as compared to untreated $(0 \mu \mathrm{M}){ }^{\mathrm{a}} \mathrm{p} \leq 0.01$

(Schmid et al., 2000; Birbach et al., 2002; Swinney et al., 2002). Notably, our study demonstrates that exposure to acetoxyroyleanone resulted in remarkable downregulation in the expression of NF- $\mathrm{KB}$ (p65). Furthermore, caspases play a central role in apoptosis and are central to the mechanism of apoptosis as they are both the initiators and executioners. Among caspases, caspase-3 is a frequently activated death protease, which catalyzes the specific cleavage of many key cellular proteins resulting apoptosis (Porter and Jänicke, 1999). Importantly, caspase-3 is crucial for apoptotic chromatin condensation and DNA fragmentation in all cell types. Here, it is reported that acetoxyroyleanone mediates caspase- 3 up-regulation in colo-205 cells. Taken together, these data indicate that NF$\mathrm{\kappa B}$ and caspase-3 play a pivotal role in mediating acetoxyroyleanone-induced apoptosis in Colo-205 cells.

Cell migration plays a critical role in tumor cell invasion and metastasis (Yamaguchi et al., 2005). Importantly, cell migration and invasion represents an important property for chemotherapeutic agent other than having the potential to cause specific cancer cell death. Molecules involved in cancer cell migration could be the potential target for anti-metastasis therapy.

This study describes how colon cancer cell migrate using acetoxyroyleanone tested by measuring the gap between control and treatment groups. Acetoxyroyleanone was found actively inhibit colon cancer cell migration. Notably, apoptosis is morphologically characterized by chromatin condensation, internucleosomal fragments, cell shrinkage, membrane blebbing and formation of apoptotic bodies without disruption of the plasma membrane (Wyllie et al., 1984).

\section{Conclusion}

Acetoxyroyleanone has a target based antiproliferative activity. A successful anticancer drug must have the ability to induce tumor cell apoptosis and these results showed that acetoxyroyleanone does show this characteristic feature of inducing apoptosis in Colo-205 cancer cells.

\section{References}

Bhart AC, Donato N, Singh S, Aggarwal BB. Curcumin (diferuloylmethane) down-regulates the constitutive activation of nuclear factor-kappa B and kappa-B alpha kinase in human multiple myeloma cells, leading to suppression of proliferation and induction of apoptosis. Blood 2003; 101: 1053-62.

Birbach A, Gold P, Binder BR, Hofer E, de Martin R, Schmid JA. Signaling molecules of the NF-kappa B pathway shuttle constitutively between cytoplasm and nucleus. J Biol Chem. 2002; 277: 10842-51.

da Araújo EC, Lima MA, Montenegro RC, Nogueira M, CostaLotufo LV, Pessoa C, de Moraes MO, Silveira ER. Cytotoxic abietane diterpenes from Hyptis martiusii Benth. Z Naturforsch C. 2006; 61: 177-83.

Fronza M, Lamy E, Günther S, Heinzmann B, Laufer S, Merfort I. Abietane diterpenes induce cytotoxic effects in human pancreatic cancer cell line MIA PaCa-2 through different modes of action. Phytochemistry 2012; 78: 107-19. 
Garg A, Aggarwal BB. Nuclear transcription factor-kappaB as a target for cancer drug development. Leukemia 2002; 16: 1053-68.

Jemal A, Bray F, Center MM, Ferlay J, Ward E, Forman D. Global cancer statistics. CA Cancer J Clin. 2011; 61: 69-90.

Kinzler KW, Vogelstein B. Lessons from hereditary colorectal cancer. Cell 1996; 87: 159-70.

Porter AG, Jänicke RU. Emerging roles of caspase-3 in apoptosis. Cell Death Differ. 1999; 6: 99-104.

Rodrigues NR, Rowan A, Smith ME, Kerr IB, Bodmer WF, Ganon JV, Lane DP. p53 mutations in colorectal cancer. Proc Natl Acad Sci USA. 1990; 87: 7555-59.

Rupnarain C, Dlamini Z, Naicker S, Bhoola K. Colon cancer: Genomics and apoptotic events. Biol Chem. 2004; 385: 44964 .

Schmid JA, Birbach A, Hofer-Warbinek R, Pengg M, Burner U, Furtmüller PG, Binder BR, de Martin R. Dynamics of NF kappa B and IkappaB alpha studied with green fluorescent protein (GFP) fusion proteins: Investigation of GFP-p65 binding to DNA by fluorescence resonance energy transfer. J Biol Chem. 2000; 275: 17035-42.

Shen HM, Tergaonkar V.NF-kappa-B signaling in carcinogenesis and as a potential molecular target for cancer therapy. Apoptosis 2009; 14: 348-63.

Swinney DC, Xu YZ, Scarafia LE, Lee I, Mak AY, Gan QF, Ramesha CS, Mulkins MA, Dunn J, So OY, Biegel T, Dinh M, Volkel P, Barnett J, Dalrymple SA, Lee S, Huber M. A small molecule ubiquitination inhibitor blocks NF-kappa B -dependent cytokine expression in cells and rats. J Biol Chem. 2002; 277: 23573-81.

Vlasova GF, Romanova AS, Perel'son ME, Ban'kovskii AI. Isolation of 7-acetoxyroyleanone from Salvia nemorosa. Chem Nat Compounds. 1969; 5: 266-67.

Wyllie AH, Morris RG, Smith AL, Dunlop D. Chromatin cleavage in apoptosis: Association with condensed chromatin morphology and dependence on macromolecular synthesis. J Pathol. 1984; 142: 67-77.

Yamaguchi H, Wyckoff J, Condeelis J. Cell migration in tumors. Curr Opin Cell Biol. 2005;17: 559-64. 


\section{Your feedback about this paper}

1. Number of times you have read this paper 0

2. Quality of paper Click

3. Your comments

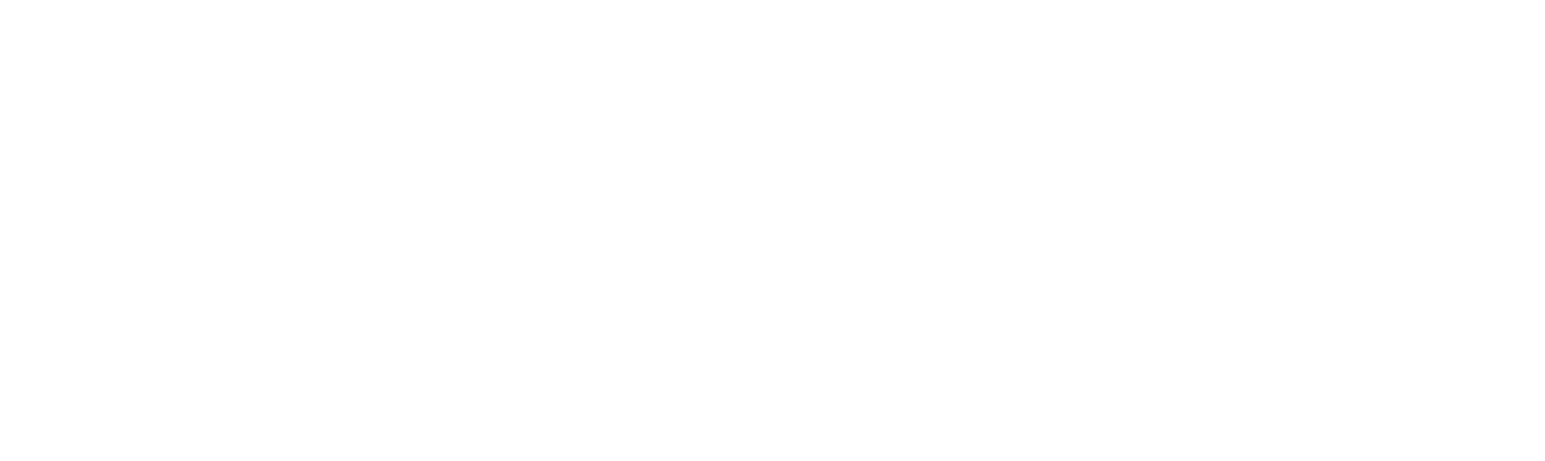

